\title{
PERAN NOTARIS DALAM PELAKSANAAN PERJANJIAN BANGUN BAGI ANTARA ORANG-PERORANGAN DI KOTA JAMBI
}

\author{
Triamy Rostarum \\ ${ }^{1}$ Fakultas Hukum, Universitas Batanghari \\ triamyrostarum@gmail.com
}

\begin{abstract}
The form of conveyance are not only through legal act sales and purchase agreement. Land owners who want to build a building in their land,but do not have the funds (capital) can do the deed of the build and sharing Agreement. Build and sharing agreement is a legal agreement between a person who was land owner and another party(second party) who is given the right to build on the land, on condition that the profits are divided into two: for the land owner and the developer. Build and sharing agreement can be made by a notarial deed as an autenthic deeds. Notary as an official appointed by the State authorities in making the deed of build and sharing agreement. Notary is the instrumental intranslating carefully and clearly explained the intent of the parties, thus achieved an agreement between the parties.The role of notary is more than that set in the Act, notary act as mediator in differences of views against something in a legal agreement between two parties. Also, notary must explain the risks and constraints that may be encountered later in the implementation of the build and sharing agreement and mediate in seeking the prevention and solution to these constraints. The constraints faced in the implementation of build and sharing agreement are construction delay; negligence committed by second party and occurred problems in land ownership.
\end{abstract}

Keywords: Build and sharing Agreement, the role of the notary.

\section{PENDAHULUAN}

Tanah yang ada diseluruh wilayah Republik Indonesia merupakan karunia Allah SWT bagi Bangsa Indonesia dan merupakan kekayaan nasional.Tanah mempunyai juga nilai ekonomis yang dapat dicadangkan sebagai sumber pendukung kehidupan individu itu sendiri sebagai manusia dimasa mendatang.Hal tersebut dikarenakan disanalah manusia hidup, tumbuh dan berkembang bahkan secara sekaligus merupakan tempat dikebumikan pada saat meninggal dunia, oleh sebab itu tanah selain memiliki nilai ekonomi yang tinggi juga mengandung aspek spiritual.

Tanah dewasa ini telah menjadi barang yang sangat bernilai lebih bahkan berharga melebihi daripada emas, bahkan tanah merupakan salah satu barang yang dinilai sangat penting oleh negara. Negara mencegah agar setiap jengkal tanah di Indonesia tidak jatuh ketangan asing, tanah juga berperan besar dalam mengatur hidup orang banyak baik untuk mendirikan rumah tinggal maupun menjadi sumber penghasilan, mata pencaharian dan bahkan menjadi komoditas ekonomi. ${ }^{1}$ Tanah dapat

${ }^{1}$ Eka Rachman Wahyudi, 2015, Pertanggungjawaban Notaris Terhadap Akta Perjanjian Build, Operate, and Transfer (BOT) Yang Telah Melampaui Batas Waktu Menurut UUPA. Badung, Universitas Udayana 
dimanfaatkan untuk keperluan pertanian, peternakan, perikanan, dan perkebunan.Tanah juga dapat dipergunakan untuk keperluan mendirikan bangunan, contohnya rumah/hunian, ruko, sekolah, rumah sakit, perkantoran, pabrik, bandar udara, dan lain-lain.

Pembangunan nasional sebagai rangkaian upaya pembangunan yang berkesinambungan yang meliputi seluruh aspek kehidupan masyarakat bangsa dan negara yang berlangsung tanpa henti untuk melaksanakan tugas mewujudkan tujuan nasional sebagaimana dirumuskan dalam Pembukaan Undang-Undang Dasar Negara Republik Indonesia Tahun 1945, membutuhkan tanah yang cukup luas sedangkan persediaan tanah sangat terbatas baik jumlah maupun luasnya yang bersifat tetap dan tidak bertambah dalam segala dimensi kebutuhan manusia. Keterbatasan akan sumber daya tanah, berhadapan dengan peningkatan kebutuhan tanah bagi pelaksanaan pembangunan, di satu sisi membawa dampak positif meningkatnya harga tanah, tetapi di pihak lain membawa dampak negatif menjadi salah satu pemicu timbulnya sengketa/konflik pertanahan.

Pertumbuhan ekonomi Kota Jambi dapat terlihat melalui pembangunan hotel berbintang, perumahan, pertokoan, pusat perbelanjaan, hingga swalayan. Saat ini para investor di Kota Jambi seakan berlomba-lomba untuk membangun perumahan, pertokoan/ruko dan pusat perbelanjaan. Pembangunan perumahan, pertokoan, perhotelan dan lain-lainnya itu membutuhkan area lahan/tanah. Hal ini menyebabkan tanah kosong diperkotaan semakin langka dan harga semakin mahal. Selain tanah, pembangunan ini juga membutuhkan biaya untuk bahan bangunan dan konstruksi, dan biaya yang dibutuhkan juga tidak kecil. Besarnya biaya ini menjadi salah satu kendala bagi investor dan juga pemilik tanah/lahan yang ingin ikut dalam kegiatan pembangunan di Kota Jambi.

Salah satu solusi untuk dapat berinvestasi dalam kegiatan pembangunan di Kota Jambi dengan keterbatasan lahan adalah dengan melakukan perjanjian kerjasama untuk pemanfaatan lahan yang ada. Perjanjian kerjasama untuk pemanfaatan lahan tersebut di atas antara orang-perorangan yang sering digunakan adalah perjanjian bangun bagi. Bentuk perjanjian adalah kerja sama yang dilakukan antara pemegang hak atas tanah dengan investor, yang menyatakan bahwa pemegang hak atas tanah memberikan hak kepada investor untuk mendirikan bangunan selama masa perjanjian, dan mengalihkan kepemilikan bangunan tersebut kepada pemegang hak atas tanah setelah masa guna serah berakhir. ${ }^{2}$

Perjanjian bangun bagi ini berkembang dalam masyarakat sebagai akibat adanya kebiasaan dalam masyarakat melakukan kegiatan bagi hasil. Perjanjian bagi hasil ini timbul dari adanya keinginan dua pihak atau lebih saling bekerja sama untuk suatu kegiatan usaha yang kemudian hasil usahanya dibagi sesuai dengan kesepakatan antara para pihak yang terlibat dalam perjanjian.

Pelaksanaan perjanjian bangun bagi sering dilakukan oleh pihak developer dengan pemilik tanah. Perjanjian bangun bagi dapat terjadi apabila pemilik tanah dan developer sepakat untuk melakukan suatu perjanjian, adapun perjanjian tersebut

${ }^{2}$ Ima Oktorina. 2010. Kajian Tentang Kerjasama Pembiayaan dengan Sistem BOT dalam Revitalisasi Pasar Tradisional. Universitas Diponegoro : Semarang. Hlm. 12. 
berisi bahwa pemilik tanah memberikan ijin kepada developer untuk mengelola tanahnya dengan cara membangun beberapa unit rumah toko dan rumah toko tersebut merupakan objek perjanjian yang akan dibagi oleh para pihak sesuai dengan kesepakatan. Selain itu, perjanjian bangun bagi ini juga bisa dilakukan oleh orang pribadi bersama orang lain atau orang perorangan.

Perjanjian Bangun Bagi rentan terhadap sejumlah risiko, risiko umum yang sering terjadi pada Perjanjian Bangun Bagi adalah: (1). Risiko Konstruksi (construction and operation risk), yaitu risiko konstruksi bangunan yang diinginkan tidak dapat terealisasi hingga waktu yang telah ditentukan. Kemungkinan keterlambatan penyelesaian konstruksi ini seharusnya dimasukkan juga dalam kontrak atau perjanjian yaitu dengan mencantumkan pengenaan denda atau ganti rugi untuk suatu keterlambatan atau meminta jaminan pelaksanaan (performance bond) pada tingkatan yang berbeda. (2). Risiko membengkaknya biaya yang melebihi perkiraan biaya semula. Jika terjadi hal seperti ini, maka dapat diperjanjikan dalam kontrak adanya harga yang pasti atau dapat pula diupayakan risiko tersebut ditanggung bersama antar para pihak. (3). Risiko musibah yang disebabkan oleh bencana alam seperti banjir, gempa, badai, yang mana hal ini sebaiknya diatasi dengan asuransi. Bukan hanya risiko, perjanjian bangun bagi juga pastinya memiliki kendala dalam pelaksanaannya.

Seperti halnya akta perjanjian pada umumnya, pembuatan akta perjanjian Bangun Bagi dilakukan dihadapan Notaris. Notaris keberadaannya sangat penting yakni membuat alat bukti otentik berupa akta. Notaris saat menjalankan tugas dan jabatannya tersebut, harus berdasar dan sejalan dengan ketentuan peraturan perundang-undangan jabatan dan kode etik serta yang berkaitan dengan dibuatnya suatu akta otentik. Ketentuan tersebut diatur dalam Undang-Undang Republik Indonesia Nomor 02 Tahun 2014 tentang Perubahan Atas Undang-Undang Nomor 30 Tahun 2004 tentang Jabatan Notaris (selanjutnya disebut dengan UUJN-P). ${ }^{3}$

Peranan seorang notaris senantiasa diperlukan oleh masyarakat, terlebih masyarakat yang sedang membangun bahkan setiap individu memerlukan jasa notaris, sebagai contoh dalam kehidupan sehari-hari, misalnya mendirikan suatu badan usaha, perjanjian jual-beli, tukar menukar, perjanjian kredit dan lain sebagainya. Bahkan seseorang yang akan berwasiat sebelum meninggal dunia, menuangkan kehendak terakhirnya dalam akta wasiat yang dibuat dihadapan seorang notaris.

Notaris sebagai ahli dalam bidang hukum dapat memberi bantuannya, baik berupa nasehat-nasehat maupun dengan penyusunan akta-akta yang sedemikian rupa, sehingga dapat dicapai apa yang dibutuhkan oleh pihak-pihak yang membutuhkan jasa notaris. Dalam penyusunan akta terletak keterampilan dan seni dari seorang notaris dalam menerapkan hukum, sehingga dapat memenuhi maksud dan keinginan dari pihak-pihak yang membuat perjanjian, salah satunya adalah Perjanjian Bangun Bagi.

${ }^{3}$ Eka Rachman Wahyudi, 2015, Pertanggungjawaban Notaris Terhadap Akta Perjanjian Build, Operate, and Transfer (BOT) Yang Telah Melampaui Batas Waktu Menurut UUPA. Badung, Universitas Udayana 
Berdasarkan uraian tersebut di atas, penulis merasa tertarik membahas lebih dalam melalui penulisan hukum mengenai bagaimana "Peran Notaris dalam Pembuatan Akta Perjanjian Bangun Bagi antara orang perorangan di Kota Jambi".

\section{Rumusan Masalah}

Berdasarkan uraian pada latar belakang diatas, maka penulis mengambil beberapa perumusan masalah antara lain sebagai berikut:

1. Bagaimana peran notaris dalam pelaksanaan pembuatan Perjanjian Bangun Bagi antara orang-perorangan di Kota Jambi?

2. Apa saja kendala yang dihadapi Notaris dalam pelaksanaan Perjanjian Bangun Bagi?

Penelitian ini bertujuan untuk mengetahui bagaimana peran Notaris dalam pelaksanaan pembuatan Perjanjian Bangun Bagi antara orang-perorangan di Kota Jambi serta mengetahui dan memahami kendala yang dihadapi dalam pelaksanaan Perjanjian Bangun Bagi sehingga masyarakat mengetahui bagaimana pelaksanaan perjanjian bangun bagi di Kota Jambi.

\section{METODOLOGI PENELITIAN}

Karya ilmiah harus disusun secara jelas dan sistematis berdasarkan fakta-fakta yang dapat dipercaya kebenarannya dari data-data yang diperoleh, sehingga sebelum memulai suatu penulisan diperlukan adanya penelitian.Untuk itu maka penulis memilih metode yang sesuai dengan masalah yang akan diteliti. ${ }^{4}$ Suatu penelitian dilakukan dengan mengikuti metode atau tatacara tertentu.Secara etimologis metode di artikan sebagai jalan atau cara melakukan atau mengerjakan sesuatu, metode berasal dari bahasa Yunani "Methodos" yang artinya "jalan menuju", bagi kepentingan ilmu pengetahuan, metode merukan titik awal menuju proposisiproposisi akhir dalam bidang ilmu pengetahuan tertentu. ${ }^{5}$ Dalam metode penelitian merupakan cara dan prosedur yang sistematis dan terorganisir untuk menyelidiki suatu masalah tertentu dengan maksud mendapatkan informasi untuk digunakan sebagai solusi atas masalah, oleh karena itu metode merupakan keseluruhan langkah ilmiah yang digunakan untuk menemukan solusi atas suatu masalah. ${ }^{6}$

Metode penelitian yang didasarkan pada judul dan permasalahan bersifat empiris. Penelitian hukum empiris menggunakan studi kasus hukum empiris berupa perilaku hukum masyarakat. ${ }^{7}$ Pokok kajiannya adalah hukum yang dikonsepkan sebagai perilaku nyata (actual behavior) sebagai gejala sosial yang sifatnya tidak tertulis, yang dialami tiap orang dalam hubungan bermasyarakat.Sumber data penelitian hukum empiris tidak bertolak pada hukum postif tertulis, melainkan hasil

\footnotetext{
${ }^{4}$ Sri Mamudji et al., 2005,Metode Penelitian dan Penulisan Hukum, Jakarta, Badan Penerbit Fakultas Hukum Universitas Indonesia, hal.2.

${ }^{5}$ Soerjono Soekanto, 2007, Pengantar Penelitian Hukum, UI Press, Jakarta, hal 43

${ }^{6}$ Ulber Silalahi, 2009, Metode Penelitian Sosial, Refika Aditanam, Bandung, hal 29

${ }^{7}$ AbdulKadir Muhammad, 2004, Hukum dan Penelitian Hukum, PT. Citra Aditya Bakti, Bandung, Cet.1, hal 40.
} 
observasi di lokadi penelitian. ${ }^{8}$ Pendekatan terhadap masalah dengan melihat dan memperhatikan norma hukum yang berlaku dihubungkan dengan fenomenafenomena yang ada dari permasalahan yang ditemui dalam penelitian.

Lokasi penelitian dilaksanakan di beberapa Kantor Notaris di Kota Jambi.Objek penelitian adalah Notaris di Kota Jambi sebagai Pejabat Umum yang berwenang membuat perjanjian.Data yang digunakan dalam penelitian ini dikelompokkan menjadi dua, yaitu:

1) Data primer

merupakan data diperoleh secara langsung melalui observasi terhadap objek peneliti, dalam penelitian ini adalah beberapa notaris di Kota Jambi.

2) Data sekunder

merupakan data yang bersumber dari buku-buku yang berhubungan dengan objek penelitian.

Teknik pengumpulan data yang digunakan adalah wawancara serta diskusi yang dilakukan penulis dengan notaris-notaris untuk memperoleh data yang digunakan dalam penelitian.Wawancara kualitatif dilakukan bila peneliti bermaksud untuk memperoleh pengetahuan tentang makna-makna subjektif yang dipahami individu, berkenaan dengan topik yang diteliti dengan maksud melakukan eksplorasi terhadap isu tersebut.

\section{HASIL DAN PEMBAHASAN}

\section{Peran Notaris dalam Pelaksanaan Pembuatan Perjanjian Bangun Bagi}

Hukum perjanjian merupakan bagian dari hukum perikatan, bahkan sebagian ahli hukum menempatkan sebagai bagian dari hukum perjanjian karena kontrak sendiri ditempatkan sebagai perjanjian yang dibuat dalam bentuk tertulis. ${ }^{9}$ Perjanjian bangun bagi belum secara khusus ada pengaturannya. Oleh karena itu, hukum perjanjian menjadi dasar dilakukannya perjanjian bangun bagi ini.Perjanjian diatur dalam Bab II Buku III KUH Perdata, sedangkan mengenai perjanjian-perjanjian secara khusus diatur dalam Bab V sampai dengan Bab VIII. Menurut Pasal 1313 KUH Perdata, "suatu perjanjian adalah suatu perbuatan dengan mana satu orang atau lebih mengikatkan dirinya terhadap satu orang lain atau lebih". ${ }^{10}$

Abdul Kadir Muhammad memberikan pengertian perjanjian sebagai suatu persetujuan dengan mana dua orang atau lebih saling mengikatkan diri untuk melaksanakan suatu hal dalam lapangan harta kekayaan. ${ }^{11}$ Perjanjian ini merupakan suatu peristiwa hukum di mana seorang berjanji kepada orang lain atau dua orang saling berjanji untuk melakukan atau tidak. Apabila dua orang saling berjanji, ini berarti masing-masing pihak berhak untuk menerima apa yang diperjanjikan oleh pihak lain. Hal ini berarti bahwa masing-masing pihak dibebani kewajiban dan diberi hak sebagaimana yang dijanjikan melakukan sesuatu

\footnotetext{
${ }^{8}$ Ibid, hal 54

${ }^{9}$ Ahmadi Miru, Hukum Kontrak, 2007, PT Raja Grafindo Persada, Jakarta

${ }^{10}$ R. Subekti, dan R. Tjitrosudibio, 2003, Kitab Undang-undang Hukum Perdata (KUH Perdata), PradnyaParamita, Jakarta

${ }^{11}$ Abdul Kadir Muhammad,1989, Hukum Perjanjian, Mandar Maju, Bandung.
} 
Perjanjian bangun bagi orang-perorangan antara pemilik tanah dengan pelaksana pembangunan dalam praktek secara umum berpedoman pada ketentuan pada asas kebebasan berkontrak Pasal 1338 ayat (1) jo Pasal 1320 KUHPerdata. Dasar timbulnya perjanjian bangun bagi ini adalah sama halnya dengan perjanjian bagi hasil atau dalam perjanjian pembangunan disebut perjanjian bangun bagi karena orang yang mempunyai hak atas tanah tidak mempunyai kesempatan ataupun kemampuan untuk membangun atau mendirikan bangunan sesuai yang diinginkannya. Oleh karena itu, dengan membuat kesepakatan atau perjanjian bangun bagi tersebut pemilik tanah mengizinkan orang lain untuk membangunnya dengan ketentuan agar hasilnya dalam hal ini dibagi dua atau sesuai dengan kesepakatan.

Perjanjian bangun bagi dikatakan sah apabila mengikuti syarat-syarat berdasarkan Pasal 1320 KUHPerdata syarat sahnya perjanjian ${ }^{12}$, yaitu:

a. Sepakat mereka yang mengikat dirinya

Maksudnya adalah bahwa kedua subyek yang mengadakan perjanjian itu harus bersepakat, setuju dan sepakat mengenai hal-hal yang pokok dari perjanjian yang diadakan itu.Apa yang dikehendaki pihak yang satu, juga dikehendaki pihak yang lain. Mereka menghendaki sesuatu yang sama secara timbal balik, yang sesuai dengan kemauan yang bebas para pihak.

b. Cakap Untuk Membuat Suatu Perjanjian

Pihak-pihak yang membuat kontrak haruslah orang-orang yang cakap hukum atau sudah dewasa. Orang dikatakan dewasa terdapat dalam pasal 330 KUH Perdata, orang dewasa adalah orang yang sudah berumur 21 tahun atau sudah pernah kawin dan bukan dalam berada pengampuan meskipun umurnya sudah mencapai 21 tahun.Subjek yang dianggap cakap membuat persetujuan ialah orang yang mampu melakukan tindakan hukum.Umumnya mereka yang mampu melakukan tindakan hukum ialah orang dewasa yang berakal sehat.

c. Mengenai Suatu Hal Tertentu

artinya, objek yang diperjanjikan jelas atau setidak-tidaknya dapat ditentukan, tidak boleh mengabang ataupun samar-samar.Adanya objek dan syarat berguna untuk hak kewajiban kedua pihak.

d. Suatu Sebab Yang Halal

Kesepakatan yang tertuang di dalam perjanjian tidak boleh bertentangan dengan perundang-undangan, menganggu ketertiban umum dan kesusilaan.

Berdasarkan Pasal 1338 KUHPerdata yang menentukan sebagai berikut, semua perjanjian yang dibuat oleh para pihak berlaku sebagai undang-undang bagi mereka yang membuatnya.Pasal tersebut digunakan sebagai dasar hukum bagi segala macam jenis perjanjian yang dibuat oleh para pelaku bisnis, termasuk di dalamnya adalah perjanjian bangun bagi.

Individu atau subjek hukum yang dapat membuat perjanjian adalah individu yang mempunyai kecakapan untuk suatu perbuatan hukum.Hal ini penting untuk kelancaran dari pelaksanaan perjanjian karena kecakapan subjek hukum syarat subjektif dari syarat sahnya suatu perjanjian, apabila syarat tersebut tidak terpenuhi, maka perjanjian tersebut dapat dibatalkan.

\footnotetext{
${ }^{12}$ R. Subekti, dan R. Tjitrosudibio, 2003, Kitab Undang-undang Hukum Perdata (KUH Perdata), PradnyaParamita, Jakarta
} 
Perjanjian Bangun Bagi terjadi dengan pemilik tanah memberi hak dankewenangan kepada pihak lain untuk membangun bangunan-bangunan di atas tanah milik pemilik tanah, yang mana setelah selesainya pembangunan bangunan tersebut, atau dari awal sudah disepakati bagian masing-masing pihak untuk memiliki tanah dan bangunan yang dibagi berdasarkan kesepakatan para pihak yang perjanjiannya dapat dibuat secara dibawah tangan maupun dengan akta notaris.Dalam perjanjian ini pihak pemilik tanah menyediakan tanahnya untuk dibangun sejumlah bangunan dengan suatu kesepakatan pembagian suatu hubungan hukum dan seterusnya tinggal menerima bagian yang menjadi haknya.Sedangkan pelaksana pembangunan melaksanakan pembangunan sesuai kesepakatan dan juga memperoleh bagian dari bangunan yang menjadi haknya.

Dalam hal dua orang mengadakan suatu perjanjian, maka timbul hak bagi pihak yang satu menjadi kewajiban bagi pihak lain yang dalam KUH Perdata pihak pertama disebut debitur dan pihak kedua disebut kreditur. Pelaksanaan perjanjian bangun bagi ini juga merupakan perjanjian konsensuil (timbal balik) dan sebagai suatu perjanjian timbal balik, maka yang menjadi kewajiban pemilik tanah merupakan hak dari pemilik modal atau pelaksana pembangunan. Sebaliknya apa yang menjadi kewajiban investor atau pelaksana pembangunan merupakan hak bagi pemilik tanah. Perjanjian bangun bagi berisikan hak dan kewajiban pihak-pihak yang membuat perjanjian tersebut, di dalamya pihak investor/pihak pelaksana pembangunan diberi hak untuk membangun bangunan dan mendapatkan hak atas tanah dan bangunan sesuai kesepakatan.Pihak pelaksana pembangunan berkewajiban untuk menanggung biaya konstruksi bangunan tersebut.

Berdasarkan hasil penelitian di Kota Jambi dalam pelaksanaan perjanjian bangun bagi, yang menjadi hak dari pihak pertama/pemilik tanah adalah mendapatkan atau memperoleh hasil berupa sejumlah unit bangunan sesuai dengan perjanjian atau ketentuan yang diperjanjikan dan jangka waktu yang telah ditentukan dalam perjanjian.Hak lainnya adalah pihak pertama mengawasi hasil pelaksanaan pekerjaan usaha pembangunan khususnya dalam penggunaan material sesuai dengan perjanjian, mengambil tindakan apabila terjadi penyalahgunaan bahan material dan apabila tidak menerima bagian sebagaimana yang diperjanjikan.Kewajiban pihak pertama, yaitu menyerahkan tanah miliknya untuk dipergunakan oleh pelaksana pekerjaan usaha pembangunan, wajib menyerahkan dan mengakui bagian dari hasil pembangunan yang menjadi hak pelaksanaan pekerjaan usaha pembangunan sesuai dengan perjanjian.

Pihak kedua/pelaksana pembangunan memiliki hak untuk mendapatkan bagian atas hasil pembangunan sesuai dengan bagian yang menjadi bagiannya sebagai imbalan dari pekerjaan yang telah dikerjakannya. Sedangkan yang menjadi kewajiban pelaksana pembangunan adalah wajib melaksanakan pembangunan sesuai dengan perjanjian dan menjaga agar tanah tidak dipergunakan sesuatu tidak sesuai dengan perjanjian merugikan lingkungan di sekitarnya, melaksanakan pekerjaan pembangunan yang menjadi objek perjanjian sesuai dengan rencana dan persyaratan serta menggunakan material sesuai dengan yang diperjanjikan, wajib menyerahkan bagian bangunan yang menjadi bagian hak pihak pertama. 
Sebagai sebuah profesi, Notaris terikat dengan peraturan dari profesinya tersebut yang kita kenal juga dengan istilah kode etik (kode etik notaris).Kode Etik Notaris dilandasi oleh kenyataan bahwa Notaris sebagai pengemban profesi adalah orang yang memiliki keahlian dan keilmuan dalam bidang kenotariatan, sehingga mampu memenuhi kebutuhan masyarakat yang memerlukan pelayanan dalam bidang kenotariatan.

Secara pribadi Notaris bertanggung jawab atas mutu pelayanan jasa yang diberikannya.Notaris merupakan perwujudan dan personifikasi dari hukum keadilan, kebenaran dan merupakan jaminan adanya kepastian hukum bagi masyarakat.Seorang notaris biasanya dianggap sebagai seorang pejabat tempat seorang dapat memperoleh nasehat yang dapat diandalkan. Segala sesuatu yang ditulis serta ditetapkan adalah benar, ia adalah pembuat dokumen yang kuat dalam suatu proses hukum.Tugas notaris memberikan bantuan tentang membuat akta otentik.Dan demikian, penting bagi notaris untuk dapat memahami ketentuan yang diatur oleh undang-undang supaya masyarakat umum yang tidak tahu atau kurang memahami aturan hukum, dapat memahami dengan benar serta tidak melakukan hal-hal yang bertentangan dengan hukum.

Menurut UU No. 2 Tahun 2014.jo. UU No 30 Tahun 2004 Pasal 15 ayat (1), tentang Kewenangan Notaris, menyebutkan:

"Notaris berwenang membuat Akta autentik mengenai semua perbuatan, perjanjian, dan penetapan yang diharuskan oleh peraturan perundangundangan dan/atau yang dikehendaki oleh yang berkepentingan untuk dinyatakan dalam Akta autentik, menjamin kepastian tanggal pembuatan Akta, menyimpan Akta, memberikan grosse, salinan dan kutipan Akta, semuanya itu sepanjang pembuatan Akta itu tidak juga ditugaskan atau dikecualikan kepada pejabat lain atau orang lain yang ditetapkan oleh undangundang." 13

Perjanjian bangun bagi dibuat dengan akta notaris sebagai akta otentik.Akta notaris merupakan keinginan para pihak yang datang menghadap notaris, tanpa adanya keinginan seperti itu, akta notaris tidak akan pernah dibuat, kewajiban notaris mengkonstatir suatu perbuatan-perbuatan sebagai suatu peristiwa konkrit, mengkonstituir peristiwa konkrit tersebut sebagai suatu peristiwa hukum untuk ditemukan bentuk atau jenis peristiwa atau perbuatan hukumnya, yang selanjutnya memverlijden seluruh rangkaian peristiwa-peristiwa atau perbuatan-perbuatan hukum untuk dibuat menjadi atau kedalam suatu akta dan akhirnya disahkan (ditanda tangani) oleh notaris, sehingga akta tersebut dikualifikasikan sebagai akta otentik. Isi akta yang bersangkutan merupakan kehendak para pihak, bukan kehendak atau keinginan notaris.

Menurut UU No. 2 Tahun 2014.jo. UU No 30 Tahun 2004 Pasal 15 ayat 2a, yaitu "Notaris berwenang pula memberikan penyuluhan hukum sehubungan dengan pembuatan Akta."Berdasarkan undang-undang ini notaris harus memberikan penjelasan kepada para pihak, agar tindakannya yang dituangkan dalam akta sesuai dengan aturan hukum yang berlaku.Jika akta notaris yang bersangkutan, dirasakan

${ }^{13}$ Undang-Undang Nomor 2 Tahun 2014 Tentang Perubahan Atas Undang-Undang Nomor 30 Tahun 2004 Tentang Jabatan Notaris. 
oleh para pihak tidak mencapai tujuan yang diinginkannya atau harus diubah sesuai keadaan, maka para pihak secara bersama-sama dan sepakat datang kehadapan notaris untuk membatalkan isi akta yang bersangkutan.Hal ini sesuai dengan kewajiban notarisditerangkan dalam UU No. 2 Tahun 2014. Jo. UU No 30 Tahun 2004, Pasal 16 ayat 1, yang menyebutkan bahwa, dalam menjalankan jabatannya, Notaris berkewajiban bertindak jujur, saksama, mandiri, tidak berpihak, dan menjaga kepentingan pihak yang terkait dalam perbuatan hukum. ${ }^{14}$

Notaris di dalam pembuatan akta perjanjian bangun bagi harus adil dan tidak boleh berpihak pada satu pihak sehingga menjadi berat sebelah. Klausula-klausula perjanjian yang dibuat harus sesuai dengan kesepakatan kedua belah pihak, dan tidak boleh ada klausula baku di dalam perjanjian. Dalam suatu perjanjian terdapat para pihak dimana masing-masing pihak mempunyai kewajiban yang timbul dari perjanjian yang telah disepakati bersama.Hak dan kewajiban itu harus dilaksanakan secara sukarela. Apabila hak tersebut tidak dilaksanakan atau dengan kata lain tidak memenuhi apa yang dijanjikan maka ia dikatakan melakukan wanprestasi (ingkar janji). Oleh karena itu, hak dan kewajiban dari kedua belah pihak harus seimbang.

Notaris sebelum pembuatan akta benar-benar mengenal dan memahami maksud dan tujuan dari para pihak, untuk menantisipasi konflik yang timbul. Notaris dalam pembuatan akta perjanjian bangun bagi diharuskan untuk dapat menerjemahkan kehendak yang dimiliki para pihak dengan jelas dan dapat mengakomodasi kepentingan para pihak sehingga memberikan jaminan atau kepastian secara hukum sampai dengan terealisasinya perjanjian tersebut secara definitif.Dengan demikian kekuatan keotentikan dari akta notaris tetap terjaga dimanapun dan dalam kondisi apapun. Kewajiban ini harus secara teliti dan sangat jelas dilakukan oleh notaris, karena perjanjian bangun bagi memiliki beberapa risiko.

Setiap perjanjian yang dibuat oleh para pihak selalu ada kemungkinan berpotensi konflik, termasuk perjanjian bangun bagi.Perselisihan atau sengketa kadang-kadang tidak dapat dihindari karena adanya kesalahpahaman, pelanggaran peraturan perundang-undangan, ingkar janji, kepentingan yang berlawanan dan atau kerugian pada salah satu pihak. Sumber konflik yang sering menjadi pemicu timbulnya sengketa adalah: itikad tidak baik dari salah satu pihak, kekeliruan menafsirkan kalimat-kalimat dalam kontrak, Force Majeure, wanprestasi, masalah moneter, waktu dan masalah ketentuan denda.

Risiko-risiko seperti pembengkakan biaya dan risiko konstruksi juga memungkinkan untuk terjadinya konflik.Risiko konstruksi yaitu risiko konstruksi bangunan yang diinginkan tidak dapat terealisasi hingga waktu yang telah ditentukan.risiko ini bisa disebabkan karena banyak hal misalnya karena biaya sudah terlalu besar atau sudah tidak ada biaya lagi. Keterlambatan ini merugikan pihak pemilik tanah.Notaris berperan dalam menjelaskan risiko-risiko ini dan bagaimana pencegahannya.

Notaris dalam membuat perjanjian bangun bagi, harus menjadi penengah para pihak serta menyarankan untuk membuat poinperjanjian yang mengatur suatu hal tertentu yang bersifat khusus berkaitan dengan kemungkinan peristiwa yang tidak

${ }^{14}$ Undang-Undang Nomor 2 Tahun 2014 Tentang Perubahan Atas Undang-Undang Nomor 30 Tahun 2004 Tentang Jabatan Notaris. 
dikehendaki oleh para pihak yang terjadi dikemudian hari. Notaris juga dapat menyarankan poin yang berisikan penyelesaian sengketa dalam perjanjian tersebut. Menyarankan apa saja cara yang ditempuh oleh para pihak dalam menyelesaikan konflik ini, biasanya adalah diselesaikan secara kekeluargaan (musyawarah), apabila tidak berhasil, masalah dapat diselesaikan melalui prosedur hukum yang berlaku. Baik berupa peradilan (litigasi); dan di luar peradilan (nonlitigasi) atau AlternativeDisputeResolution (ADR).

\section{Kendala-kendala yang Dihadapi Notaris dalam Pelaksanaan Perjanjian Bangun Bagi}

Dalam melaksanakan tugasnya sebagai pejabat pembuat akta, terdapat kendala-kendala yang dialami oleh Notaris dalam pembuatan akta perjanjian Bangun Bagi. Seperti dari segi administrasi, apabila persyaratan administrasi kurang lengkap, seperti harus adanya fotocopy KTP, PBB dan sertifikat tanah serta dokumen lainnya. Ketika para pihak belum bisa melengkapi persyaratan tersebut, maka akan mempelambat proses penandatanganan akta karena harus menunggu mereka untuk menyerahkan dokumen-dokumen yang diperlukan. Kehadiran para pihak juga menjadi kendala bagi notaris dalam merealisasikan perjanjian Bangun Bagi ini, sebab pihak yang tidak hadir dalam penandatanganan akta perjanjian sehingga perjanjian tersebut tidak dapat ditandatangani secara bersamaan maka menyebabkan tertundanya pembuatan akta perjanjian bangun bagi.

Kendala lainnya yang dihadapi dalam pelaksanaan perjanjian bangun bagi ini adalah terjadi permasalahan pada status kepemilikan tanah. Contohnya pada kasus perjanjian bangun bagi pada tanah yang merupakan tanah warisan, dimana ahli warisnya lebih dari 1 dan pada kasus tanah yang belum balik nama. Pada tanah warisan, saat pembuatan perjanjian para ahli waris sepakat dengan isi perjanjian, tetapi saat pelaksanaan perjanjian salah satu ahli waris menganggap perjanjian tidak sah dan menuntut haknya atas tanah tersebut. Pada kasus lain adalah ketika tanah tersebut belum balik nama sehingga Notaris harus melakukan pengecekan double dan membuat sertifikat tersebut balik nama atas pemilik yang sekarang atau Notaris harus menghadirkan pemilik sertifikat lama untuk dimintai tanda tangan.

Selain itu, berbagai macam risiko yang mungkin dihadapi dalam perjanjian bangun bagi, ketika benar-benar terjadi dapat menjadi kendala dalam pelaksanaan perjanjian tersebut. Di Kota Jambi risiko konstruksi yang sering terjadi, risiko inilah yang menjadi salah satu kendala pelaksanaan perjanjian bangun bagi. Pihak pelaksana pembangunan/investor melakukan apa yang dijanjikannya tetapi terlambat atau melakukan sesuatu yang tidak sesuai dengan perjanjian.Pada saat tenggat waktu yang tertera dalam perjanjian telah habis, bangunan belum selesai. Hal ini disebabkan pihak pelaksana pembangunan menunda proses pembangunan atau tidak dapat melanjutkan, sehingga proses terhenti.

Kendala ini terjadi karena pihak pelaksana pembangunan dinilai lalai dalam pelaksanaan perjanjian bangun bagi.Pada contoh kasus yang penulis temui, dimana pihak pertama, yaitu pemilik tanah membuat perjanjian dengan pihak kedua, yaitu orang melaksanakan pembangunan membuat perjanjian bangun bagi untuk pembangunan ruko diatas tanah pemilik tanpa menggunakan jasa notaris untuk 
membuat akta perjanjian.Kesepakatan dua pihak dituangkan dalam surat perjanjian yang ditandatangani di atas materai oleh kedua belah pihak yang disaksikan oleh beberapa orang saksi. Perjanjian itu berisikan bahwa dalam waktu yang dijanjikan pihak kedua akan membangun 4 ruko, setelah ruko-ruko selesai dibangun pemilik tanah akan mendapatkan 2 dari 4 ruko yang dibangun.

Perjanjian ini juga menyebutkan bahwa pemilik tanah tidak akan mengeluarkan biaya untuk pembangunan, karena biaya ditanggung oleh pihak kedua. Pihak kedua nantinya akan mendapatkan hak milik untuk 2 ruko yang tersisa.Setelah tenggat waktu pembangunan dalam perjanjian habis, pihak kedua hanya membangun 2 ruko saja sementara 2 bangunan lain belum dilakukan proses pembangunan. Pada saat pencapaian kesepakatan dalam pembuatan perjanjian tentunya sudah diperhitungkan waktu yang diperlukan oleh pihak kedua untuk membangun 4 bangunan tersebut.Kelalaian ini menimbulkan konflik antara pihak pertama dan kedua.

Contoh kasus lainnya yang terjadi adalah pihak kedua melakukan sesuatu tidak disebutkan dalam perjanjian dalam pembangunan yang merugikan pihak pertama.Misalnya pihak kedua membangun bangunan tidak sesuai dengan perjanjian.Pada kasus ini pihak kedua membangun bangunan yang luasnya tidak sesuai dengan luas bangunan dalam perjanjian. Pada kasus lain pihak kedua membangun bangunan tidak menggunakan kualitas bahan bangunan yang disebutkan di dalam perjanjian.Pelaksana pembangunan yang mengerjakan pembangunan dengan tidak melalui pertimbangan yang matang dan tidak mempergunakan material sesuai dengan perjanjian. Pelaksana pembangunan hanya melihat keuntungan yang akan diperoleh saja dan baru menyadarinya setelah pekerjaan dimulai, sehingga pada saat pekerjaan sedang berjalan terjadi perbedaan kondisi di lapangan dengan yang dimuat dalam perjanjian. Contoh kasus pertama dan kedua dapat menimbulkan konflik antara para pihak. Akibat dari konflik tersebut terhadap notaris, maka Notaris selaku pihak yang membuat akta perjanjian dapat terseret sengketa yang terjadi antara para pihak bahkan sampai ke pengadilan.

Kendala juga dapat berasal dari diri Notaris. Semakin banyak jumlah klien yang menghadap Notaris untuk membuat suatu akta otentik mengakibatkan semakin besar pula resiko kesalahan yang dibuat oleh Notaris di dalam mencantumkan keterangan para pihak di dalam akta. Ketidaktelitian dan sikap tidak berhati-hati merugikan pihak Notaris sendiri dalam pembuatan akta. Hilangnya beberapa kata atau kekhilafan di dalam mencantumkan keterangan dalam akta menjadi hal yang sering terjadi sehingga di dalam akta otentik banyak terdapat renvoi atau perubahan, penambahan, penggantian, atau pencoretan dalam akta. Jika kesalahan terjadi atas substansi perjanjian dan renvoi tidak dilakukan serta berakibat menimbulkan kerancuan atas akta, maka para pihak yang bersangkutan dapat menuntut Notaris atas akta yang dibuat.

Menggunakan jasa notaris dapat mencegah terjadinya risiko-risiko dan kendala-kendala yang mungkin akan dihadapi.Notaris dapat membantu menjabarkan risiko dan kendala tersebut didalam perjanjian dan bagaimana solusi yang bisa dilakukan sesuai dengan hukum yang berlaku ketika risiko dan kendala tersebut terjadi. Melalui penjabaran dan penjelasan tersebut para pihak dapat 
mempertimbangkan poin-poin yang akan dituangkan dalam perjanjian. Pada contoh kasus-kasus selanjutnya, jasa notaris juga sangat dibutuhkan.Notaris merupakan pejabat yang dapat menunjukkan bagaimana status hukumnya jika salah satu pihak lalai menjalankan isi perjanjian. Notaris juga dapat memberikan penyuluhan sehubungan dengan pembuatan akta, misalnya pengecekan status kepemilikan tanah yang akan digunakan.Pada kasus tanah waris notaris bisa menjamin keabsahan perjanjian bangun bagi yang dibuat.

Pembuatan perjanjian sebagaimana yang telah diuraikan sebelumnya bahwa dalam suatu perjanjian terdapat para pihak dimana masing-masing pihak mempunyai kewajiban yang timbul dari perjanjian yang telah disepakati bersama.Hak dan kewajiban itu harus dilaksanakan secara sukarela. Apabila hak dan kewajiban tersebut tidak dilaksanakan atau dengan kata lain tidak memenuhi apa yang dijanjikan maka ia dikatakan melakukan wanprestasi (ingkar janji).Adapun pengertian umum tentang wanprestasi adalah pelaksanaan kewajiban yang tidak tepat pada waktunya atau dilakukan tidak menurut selayaknya.Demikian pula halnya dalam perjanjian bangun bagi apabila salah satu pihak di dalam perjanjian bangun bagi tidak melakukan kewajibannya sebagaimana yang telah ditetapkan dalam perjanjian, maka pihak tersebut dinyatakan telah melakukan wanprestasi.Pada contoh kasus perjanjian bangun bagi yang dijelaskan sebelumnya, kasus pertama dan kedua sudah dikategorikan sebagai wanprestasi.

Ada kalanya dengan kendala-kendala yang dialami dalam pelaksanaan perjanjian bangun bagi, terjadi konflik yang tidak dapat diselesaikan dengan cara mediasi sehingga harus melalui pengadilan. Penyelesaian yang dapat dilakukan adalah proses mediasi yang merupakan salah satu bentuk alternatif penyelesaian sengketa yang bersifat konsensus/kooperatif. Proses mediasi dinilai sebagai penyelesaian sengketa yang lebih fleksibel, cepat dan responsif bagi para pihak yang bersengketa. Proses ini dilakukan melalui perundingan yang dipandu oleh mediator yang tidak memihak yang bertujuan untuk mencapai kesepakatan yang diterima oleh pihak-pihak yang bersengketa guna mengakhiri perkara.

Mediator haruslah orang yang dipercaya, bersikap netral dan memiliki keahlian dibidang yang dipersengketakan dan atau memiliki kemampuan dan kompetensi dibidang hukum, sehingga profesi-profesi hukum memungkinkan untuk menjalankan fungsi mediator jika dibutuhkan. Profesi-profesi dibidang hukum antara lain seperti hakim, advokat (pengacara), notaris, konsultan hukum, administrator hukum maupun dosen hukum yang menunjukkan kesemuanya memerlukan latar belakang pendidikan hukum, disamping pengetahuan dan keterampilan yang menunjang profesi masing-masing.

Notaris yang berwenang memberikan penyuluhan/nasihat hukum kepada para pihak dalam pembuatan perjanjian dapat menjadi mediator. Sebagaimana yang disampaikan oleh Bagir Manan pada ceramah Umum Menteri Kehakiman Republik Indonesia Bapak Oetojo Oesman, SH dalam Up Grading-Refreshing Course Notaris SeIndonesia di Bandung tanggal 29 April 1995 yang disadur oleh Hatta Poetri, Ayuningtyas (2011) mengemukakan bahwa:

Notaris dalam menjalankan jabatannya berfungsi membantu terbentuknya hukum perjanjian antara para pihak. Selain itu notaris dapat pula berfungsi 
sebagai penyuluh hukum yang dapat membantu program penyuluhan hukum, karena notaris tidak hanya sekedar membacakan akta saja kepada para penghadap sebagai pemenuhan dari formalitas yang ditentukan oleh undangundang, tetapi tentunya juga disertai penjelasan-penjelasan yuridis tentang segala sesuatu yang berkaitan dengan akta yang dibuat. ${ }^{15}$

Apabila mediasi tidak dapat menyelesaikan sengketa, maka para pihak bisa membawanya ke pengadilan.Para pihak dalam perjanjian bangun bagi yang menggunakan jasa notaris sebagai pembuat akta, bisa menggunakan akta perjanjian tersebut sebagai alat bukti yang kuat.Jalur ini tidak bisa membawa notaris sebagai tergugat di pengadilan. Penolakan diberikan memanggil notaris sebagai tergugat karena keterangan sepanjang isi akta yang dibuat oleh notaris tersebut telah menjelaskan semua, terkait dengan kasus yang terjadi, bahwa notaris sudah mengikuti standar prosedur pembuatan akta yang ada dan berdasarkan keterangan penghadap/para pihak, tetapi penghadap notaris yang berniat buruk dengan tidak memberikan data yang sebenarnya, sehingga tidak diperlukan lagi kehadiran Notaris sebagai saksi, karena akta notaris memiliki kekuatan pembuktian yang sempurna.

Notaris tidak bertanggung jawab atas kerugian yang diderita oleh pihak yang dirugikan dalam sengketa.Serta Notaris tidak dapat dituntut atas kerugian biaya pembuatan akta yang telah dibuatnya. Notaris dapat dimintakan pertanggung jawaban apabila, Notaris terbukti melakukan pelanggaran seperti perbuatan melawan hukum, misalnya dalam pembuatan akta ada unsur pemaksaan dari Notaris bagi salah satu pihak untuk menandatangani, tidak membacakan akta, dan syarat formil pembuatan akta lainnya dilanggar Notaris, bila terbukti para pihak dapat meminta ganti rugi ke Notaris. $^{16}$

\section{SIMPULAN}

Keikutsertaan notaris dalam pembentukan hukum sangat penting untuk disadari, mengingat notaris memang sangat vital peranannya sebagai pejabat negara yang berwenang membuat akta otentik. Notaris memang tidak dibebani untuk menyelidiki kebenaran materiil dari setiap akta yang dibuatnya, ia hanya bertugas mencatat apa yang dikemukakan kepadanya. Walaupun demikian, notaris wajib mencatat dengan teliti dan kritis, bahkan wajib menolak untuk membuat akta, apabila tindakan yang dilakukan oleh kliennya itu melanggar hukum, merugikan negara ataurakyat banyak.

Notaris sebagai pejabat ditunjuk oleh Negara yang berwenang dalam membuat akta perjanjian bangun bagi. Pembuatan perjanjian bangun bagi, notaris berperan dalam menerjemahkan seteliti dan sejelas-jelasnya maksud dari para pihak, sehingga tercapai kesepakatan antara para pihak. Notaris juga memberikan

${ }^{15}$ Ayuningtyas Hatta Poetri. 2011. Peranan Notaris Sebagai Mediator Ditinjau Dari Undang-Undang Nomor 30 Tahun 2004 Tentang Jabatan Notaris Dan Kode Etik Ikatan Notaris Indonesia (Ini) (Kasus: Masalah Wanprestasi Perjanjian Pinjammeminjam Tanpa Jaminan). Jakarta. Fakultas Hukum, Universitas Indonesia

${ }^{16}$ Ratih Tri Jayanati, 2010, Perlindungan Hukum Notaris Dalam Kaitannya Dengan Akta Yng Dibuatnya Manakala Ada Sengketa Di Pengadilan Negeri (Studi Kasus Putusan Pengadilan Negeri Pontianak No.72/pdtg/pn.Pontioanak), Semarang, Program Pasca Sarjana, Universitas Diponegoro 
penyuluhan hukum sehubungan dengan pembuatan Akta, berlaku adil dan tidak berpihak pada salah satu pihak sehingga menjadi berat sebelah. dan harus menjelaskan risiko-risiko dan kendala yang mungkin akan dihadapi nanti pada saat pelaksanaan perjanjian bangun bagi serta menjadi mediator dalam mencari pencegahan dan solusi akan kendala-kendala tersebut.

Meski tugas utama notaris adalah membuat atau mencatatkan kejadian secara otentik, keikutsertaan peran notaris lebih dari yang diatur di dalam undang-undang khususnya sebagai mediator dalam perbedaan pandangan terhadap sesuatu dalam hubungan hukum antar dua kliennya menjadi sangat memungkinkan. Bagi pihak yang membuat suatu perjanjian dihadapan notaris, apabila terjadi suatu konflik atau sengketa yang berhubungan dengan akta tersebut, maka biasanya orang pertama yang diminta nasihat adalah notaris yang bersangkutan.

Kendala-kendala yang dihadapi dalam pelaksanaan perjanjian bangun bagi adalah persyaratan administrasi yang belum lengkap dan ketidakhadiran pihak dalam penandatanganan akta yang memperlambat pembuatan akta perjanjian bangun bagi, masalah pada status kepemilikan tanah dan tanah yang belum balik nama, sengketa antara para pihak akibat wanprestasi perjanjian yang dapat menyeret Notaris sebagai pejabat yang membuat akta perjanjian tersebut sampai ke pengadilan. Kendalakendala ini bisa dicegah dan bisa juga mendapatkan solusi jika terjadi dengan melibatkan notaris di dalam pembuatan perjanjian bangun bagi. Notaris dapat menjabarkan dan menjelaskan sesuai dengan hukum yang berlaku bagaimana kemungkinan-kemungkinan yang akan terjadi, sehingga para pihak bisa mendapatkan kepastian hukum dalam perjanjian.

Pada prinsipnya perjanjian bagi bangun dilaksanakan dalam perjanjian yang mengikat para pihak yang beritikad baik. Dalam pelaksanaannya juga wajib sejalan dengan kepatutan, kebiasaan dan undang-undang. Para pihak seharusnya dapat membentengi kepentingannya sendiri agar tercipta kepastian dari perbuatan hukum bagi bangun tersebut. Notaris sebagai penyuluh hukum dapat berdiri sebagai penyeimbang dari kepentingan para pihak agar bermanfaat bagi para pihak.

\section{DAFTAR PUSTAKA}

Ahmadi Miru. 2007.Hukum Kontrak. PT Raja Grafindo Persada, Jakarta.

Ima Oktorina. 2010. Kajian Tentang Kerjasama Pembiayaan dengan Sistem BOT dalam Revitalisasi Pasar Tradisional. Universitas Diponegoro : Semarang. Hlm. 12.

Hatta Poetri, Ayuningtyas. 2011. Peranan Notaris Sebagai Mediator Ditinjau Dari Undang-Undang Nomor 30 Tahun 2004 Tentang Jabatan Notaris Dan Kode Etik Ikatan Notaris Indonesia (Ini) (Kasus: Masalah Wanprestasi Perjanjian Pinjammeminjam Tanpa Jaminan). Jakarta. Fakultas Hukum, Universitas Indonesia.

Jayanati, Ratih Tri. 2010, Perlindungan Hukum Notaris Dalam Kaitannya Dengan Akta Yng Dibuatnya Manakala Ada Sengketa Di Pengadilan Negeri (Studi Kasus Putusan Pengadilan Negeri Pontianak No. 72/pdtg/pn.Pontioanak). Semarang. Program Pasca Sarjana, Universitas Diponegoro. 
Kajian Ekonomi dan Keuangan Regional Provinsi Jambi Februari 2017.http://www.bi.go.id/id/publikasi/kajian-ekonomiregional/jambi/Pages/KEKR-Provinsi-Jambi-Februari-2017.aspx. Diakses pada tanggal 15 april 2017.

Mamudji, Sri et al., 2005, Metode Penelitian dan Penulisan Hukum, Jakarta, Badan Penerbit Fakultas Hukum Universitas Indonesia, hal.2.

Muhammad, AbdulKadir. 1989.Hukum Perjanjian. Mandar Maju, Bandung. , 2004, Hukum dan Penelitian Hukum, PT. Citra Aditya Bakti, Bandung, Cet.1, hal 40.

Soerjono Soekanto, 2007, Pengantar Penelitian Hukum, UI Press, Jakarta, hal 43

Subekti, R, dan R. Tjitrosudibio. 2003.Kitab Undang-undang Hukum Perdata (KUH Perdata). PradnyaParamita,Jakarta.

Ulber Silalahi, 2009, Metode Penelitian Sosial, Refika Aditanam, Bandung, hal 29

Undang-Undang Nomor 2 Tahun 2014 Tentang Perubahan Atas Undang-Undang Nomor 30 Tahun 2004 Tentang Jabatan Notaris.. 